\title{
BUDOWA KOŚCIOŁÓW KATOLICKICH DLA OSIEDLEŃCÓW POLSKICH W KRESLAWCE I KANOKU W GUBERNI JENISEJSKIEJ NA POCZĄTKU XX WIEKU
}

Emigracja z ziem polskich do różnych krajów, zaczęła przybierać znaczne rozmiary począwszy od drugiej połowy XIX w. Intensyfikacja tego zjawiska nastapiła przede wszystkim wśród mieszkańców ziem Królestwa Polskiego. Początki emigracji zarobkowej z terenów polskich zaboru rosyjskiego, skierowanej przede wszystkim do Stanów Zjednoczonych, nastapiły w latach 70 -tych XIX w. Oblicza się, że z ogólnej liczby około 1,3-1,4 mln emigrantów, którzy opuścili obszar zaboru rosyjskiego do roku 1914, spośród ludności wiejskiej, która przeważała, około 75\% udało się do Ameryki Północnej, ponad 10\% do Ameryki Południowej, reszta do różnych krajów europejskich. Ogólna liczba wychodźców z Królestwa Polskiego w głąb Rosji, według stanu z około 1910 r., wynosiła orientacyjnie 400.000 - 600.000 osób ${ }^{1}$.

Większość Polaków, którzy osiedlili się na Syberii stanowili chłopi. Według pierwszego powszechnego spisu ludności w Rosji z 1897 r. chłopi stanowili 61,9\% polskiej diaspory na Syberii ${ }^{2}$.

Kościoły rzymsko-katolickie na wsiach powstawały dzięki inicjatywom mieszkańców i nierzadko po kilkuletnich walkach z rosyjską biurokracją. Szczególnie potrzebowali kościoła polscy katolicy w gminie sałbinskiej okręgu minusińskiego, ponieważ odległość od Krasnojarska o ponad $400 \mathrm{~km}$ dawała możliwość odwiedzenia przez księdza jeden-dwa razy na rok. Już 5 czerwca 1899 r. (po 2 latach od przyjazdu) osadnicy, którzy przybyli przeważnie z guberni wołyńskiej, piszą pod adresem irkuckiego generał-gubernatora podanie: „Nigdzie w pobliżu nie mamy kościoła, ani duchowieństwa naszego wyznania. Pozbawieni jesteśmy wykonywania obrzędów. Często umieramy bez pokuty i chowamy zmarłe niemowlęta bez tajemnicy chrztu. W związku z tym, zmuszeni jesteśmy

${ }^{1}$ A. Pilch, Wstęp, w: Emigracja z ziem polskich w czasach nowożytnych i najnowszych (XVIII$X X w)$, red. A.Pilch, Warszawa 1984, s. 9.

${ }^{2}$ Zob.: Общий свод по Империи результатов разработки данных Первой Всеобщей Переписи Населения, произведенной 28 I 1897 г., т. 2, Петербург 1904. 
prosić Waszą Wysoką Osobę przyjrzeć się naszej ciężkiej sytuacji i polecić ze swojej strony niezbędne rozporządzenie o budowę na terenie naszego Ałgasztykskiej osady kościoła rzymskokatolickiego. Przy czym dodajemy, że bez wiary wiele $\mathrm{z}$ nas może popaść $\mathrm{w}$ grzechy wobec morale i religii. Chociaż jesteśmy ludźmi biednymi, jesteśmy gotowi oferować ostatnie swoje zasoby i wspomóc skarb, i później wypłacać rozchody na budowę, jeżeli to jest potrzebne". Pismo zostało podpisane przez 29 osób, min. Wincenty Plint, Ludwig Bogusz, Antoni Grabowski, Wincenty Kozonda, Adam Bogda, Isydor Szedko i inni (podpisy nieczytelne). Irkucki generał-gubernator poprosił o pomoc jenisejskiego gubernatora, tez zaś zwrócił się z pismem do jenisejskiej prawosławnej diecezji, do biskupa jenisejskiego i krasnojarskiego Jefimija. Biskup poprosił u dziekana minusińskiej parafii prawosławnej o dane dotyczące ilości katolików w gminie abakańskiej (powstała na miejscu gminy sałbińskiej) ${ }^{3}$.

Tabela 1. Liczba przesiedleńców wyznania rzymskokatolickiego we wsiach okręgu minusińskiego guberni jenisejskiej. Stan na rok 1900

\begin{tabular}{|l|c|c|c|}
\hline $\begin{array}{l}\text { Nazwa uczastka } \\
\text { (osady) }\end{array}$ & Ilość dworów (zagród) & Mężczyźni & Kobiety \\
\hline Ałgasztykski & 29 & 97 & 77 \\
\hline Tiulgiński & 17 & 65 & 44 \\
\hline Abadziulski & 11 & 62 & 7 \\
\hline Saraguszeński & 1 & 4 & 8 \\
\hline Sałbiński & 2 & 9 & 70 \\
\hline Kożuchowski & 4 & 16 & 153 \\
\hline Nowoswiniński & 2 & 10 & 416 \\
\hline Razem & 66 & 263 & \\
\hline Lączna liczna przesiedleńców & \multicolumn{2}{|c|}{} \\
\hline
\end{tabular}

Źródło: Irkuckie Obwodowe Archiwum Państwowe, zespół 25, inw.8, vol.222; Krajowe Archiwum Państwowe w Krasnojarsku, zespół 595, inw.8,vol. 2,vol.5844, k. 6.

Poparcie prośby polskich przesiedleńców wykazał w swoim raporcie od 27 IX 1900 r. do generał-gubernatora, naczelnik drugiej osady chłopskiej okręgu minusińskiego Budancew : „,...w związku z tym, że duchowny znajduje się tak daleko - w Krasnojarsku, ze swojej strony stwierdzam, iż prośba przesiedleńców jest słuszna i wymaga zaspokojenia. Brak kościoła wpływa na przybyszów przygnębiająco. To jest jedną z przyczyn powrotów"'. Mimo powyższej argumentacji przesiedleńców i miejscowych władz, jenisejski duchowny konsystorz prawosławny nie chcąc dopuścić do budowy kościoła rzymskokatolickiego, polecił gubernatorowi odmówić proszącym. Argumentowano to faktem, że: „kościoły rzymsko-katolickie budują w państwie rosyjskim w miastach, gdzie ilość miesz-

${ }^{3}$ Irkuckie Obwodowe Archiwum Państwowe, zespół 25, Главное управление Восточной Сибири (Główny Urząd Syberii Wschodniej), inw.8, vol. 222. k.1-10

${ }^{4}$ Tamże, k.11. 
kańców-katolików liczy się w tysiącach i gdzie jest wiele cerkwi. W guberni jenisejskiej mało jest cerkwi prawosławnych. W związku z czym, konsystorz uważa budowę kościoła za przedwczesną". Oprócz tego biskup Jefimij w swoim liście podaje przyczyny odmowy: ,dla budowy cerkwi potrzebne jest nie mniej niż 500 osób wiernych w parafii i 100 dworów (gospodarstw), u proszących zaś jest 66 dworów i 330 osób". Mimo wszystko, polscy katolicy nie przestali prosić władze o budowę kościoła, argumentując prawie czterokrotnym wzrostem liczby katolików w ciagu dwóch lat ${ }^{5}$.

Tabela 2. Liczba przesiedleńców wyznania rzymskokatolickiego we wsiach okręgu minusińskiego guberni jenisejskiej. Stan na rok 1902.

\begin{tabular}{|l|c|c|}
\hline \multicolumn{1}{|c|}{ Nazwa uczastka (osady) } & Mężczyźni & Kobiety \\
\hline Ałgasztykski & 158 & 162 \\
\hline Abadziulski (Malinowka) & 164 & 158 \\
\hline Tiulgiński (Kresławka) & 169 & 170 \\
\hline Sałbinski & 33 & 26 \\
\hline Ubej Tatarski & 25 & 20 \\
\hline Kożuchowski (Aleksandrówka) & 16 & 7 \\
\hline Saruszeński & 4 & 7 \\
\hline Projezży (Witebka) & 54 & 35 \\
\hline Razem & 623 & 585 \\
\hline Łączna liczba przesiedleńców & \multicolumn{2}{|c|}{1208 osób } \\
\hline
\end{tabular}

Źródło: Irkuckie Obwodowe Archiwum Państwowe, zespół 25, inw.8, vol.222; Krajowe Archiwum Państwowe w Krasnojarsku, zespół 595, inw.8, vol. 2, vol.5844.

Polacy nadal zbierali się na wiejskich zebraniach i pisali podania do władz z prośbą o rozpoczęcie budowy w jednej z osad przesiedleńczych zamieszkałych przez katolików oraz o otwarcie parafii w okręgu minusińskim. Swoje podania kierowali do gubernatora jenisejskiego, do irkuckiego generał-gubernatora oraz do Ministerstwa Spraw Wewnętrznych. Urzędnik ds. specjalnych Urzędu Przesiedleńczego Ministerstwa Spraw Wewnętrznych donosił w swoim raporcie z 20 XII 1902 r.: „,...przesiedleńcy trzech osad katolickich z mieszkańcami do 1000 osób obojga płci przedstawili decyzję wiejskich zebrań, prosząc o skierowanie do nich księdza. Zobowiązują się opłacać mu stałe wynagrodzenie po 50 kop. od każdej osoby, co wyniosłoby do 500 rubli Licząc inne rozchody za sprawowanie posługi i biorąc pod uwage, że katolicy mieszkają w sąsiadujących osadach można liczyć, że dochód księdza przekroczy 1000 r. rocznie".

Jednak, nie patrząc na gotowość chłopów gminy sałbińskiej (w latach 19001902 gmina abakańska), władze nie znalazły możliwości finansowania budowy kościoła i odpowiedziały odmownie na prośbę migrantów. W marcu 1904 r. kancelaria generał-gubernatora Wasyla Prikłonskiego donosiła jenisejskiemu gubernatorowi Michałowi Plecowi: „...rozumiejąc chęć katolików do posiadania swo-

\footnotetext{
${ }^{5}$ Tamże, k.12-14.

${ }^{6}$ Tamże. Krajowe Archiwum Państwowe w Krasnojarsku, zespół 595, Енисейское губернское управление (Jenisejski urząd gubernialny), inw.8, vol. 4765, k. 16-17.
} 
jego kościoła, generał-gubernator nie widzi możliwości okazania im jakiejkolwiek pomocy ze strony skarbu. Dlatego prośba o budowę kościoła nie została uwzględniona. Natomiast, jeżeli rzymsko-katolicy chcą wybudować kościół za własne fundusze, to Jego Mość nie znajduje ze swojej strony żadnych przyczyn na odmowę". Walka z biurokratyzmem ciagnęła się ponad pięć lat. W 1904 r. Ałgysztak już należał do nowej gminy w okręgu minusińskim - karabiełykskoj ${ }^{8}$.

$\mathrm{Z}$ wieloma prośbami do generał-gubernatora zwracał się również proboszcz ks. Leon Światopełk-Mirski ${ }^{9}$. W liście z 7 października 1904 r. do generał-majora Nikołaja Aleksiewiczas Augustowa, gubernatora jenisejskiego podkreślił: „W związku z tym, że liczba katolików, zamieszkałych w osadzie Ałgysztakskiej oraz gospodarstw nie tylko już osiagnęła normy zatwierdzonej prawem dla założenia katolickiej parafii, ale również i w związku z tym, że w gminie karabiełykskoj buduje się dwie świątynie prawosławne, nie będą upokorzone i lekceważone interesy prawosławnych mieszkańców tej gminy ${ }^{10 "}$.

Nie znajdując pomocy u władz miejscowych, przesiedleńcy zwrócili się do rzymsko-katolickich diecezji w zachodnich guberniach Rosji. W wyniku tak długich i uporczywych starań kościół został zbudowany, ale nie w Ałgasztyku, a w osadzie Tiulgińskiej - Kresławce. Po uzyskaniu pozwolenia na budowę w 1906 r. parafianie opodatkowali się po 40 kopiejek na osobę z przeznaczeniem na zakup i zwózkę materiałów, natomiast robocizna została opłacona z funduszy rządowych $^{11}$. W 1908 r. ks. Świętopełk-Mirski benedykował drewniany kościół p.w. św. Antoniego, postawiony na murowanym fundamencie ${ }^{12}$. Przy kościele założono parafię a prałat archidiecezji mohylewskiej skierował do Kresławki na stałe jako proboszcza wikarego krasnojarskiego kościoła, księdza Ksawerego Marcyniana $^{13}$.

${ }^{7}$ Krajowe Archiwum Państwowe w Krasnojarsku, zespół 595 Jenisejski urząd gubernialny, inw.8, vol. 4765, k. 16-17.

8 Krajowe Archiwum Państwowe w Krasnojarsku, zespół 595 Jenisejski urząd gubernialny, inw.8, vol. 5844. k. 15.

${ }^{9}$ Światopełk-Mirski Leon (1871-?). Pochodzenie z rodziny szlacheckiej z guberni mińskiej. Ukończył Seminarium Duchowne w Petersburgu. Wyświęcony w 1896 roku. Duszpasterzował w guberni witebskiej. Od 1918 r. przebywał poza archidiecezją. Wikariusz w Tobolsku (1897-1903). Proboszcz w: Krasnojarsku (1903-1913), Irkucku (1913-1914). Dziekan irkucki (1913-1914). (Zob: Andrzej Majdowski, Kościót katolicki w Cesarstwie rosyjskim. Syberia. Daleki Wschód. Azja Środkowa, Warszawa 2001, s. 309.)

${ }^{10}$ Krajowe Archiwum Państwowe w Krasnojarsku, zespół 595 Jenisejski urząd gubernialny, inw.8, vol. 5844 , k. 11.

${ }^{11}$ Rosyjskie Państwowe Archiwum Historyczne w Sankt Petersburgu, zespół 821 МИД. Иностранные вероисповедания (MSZ. Wyznania cudzoziemskie), inw. 125, vol. 886, k. 1-3.

${ }^{12}$ Rosyjskie Państwowe Archiwum Historyczne w Sankt Petersburgu, zespół 826 Kancelaria metropolity, inw. 1, vol. 1868, k. 1-3; Rosyjskie Państwowe Archiwum Historyczne w Sankt Petersburgu, zespół 826 Канцелярия метрополита (Kancelaria metropolity), inw. 3, vol. 44, k. 67.

${ }^{13}$ Marcinian Ksawery (1878-1918) - pochodził z rodziny chłopskiej, z guberni wileńskiej. Ukończył Seminarium Duchowne w Petersburgu i został wyświęcony w 1903 r. Wikariusz w Krasnojarsku w latach 1904-1904. Filialista w Kresławce - 1905 r. Od 1906 r. - duszpasterz w guberni witebskiej. Zamordowany przez bolszewików. (Zob.: Majdowski, Kościół katolicki 
Próba ustanowienia filii parafii Kresławce w 1905 r. skończyła się niepowodzeniem ze względu na skrajne ubóstwo parafian. Również wydelegowany z guberni witebskiej ks. Jakub Kindzul szybko wyjechał z powrotem, a ks. Wincenty Czapliński uzyskał przeniesienie na wikariat w Samarze. Najdłużej (w latach 1909-1923) w Kresławce przebywał ks. Piotr Ulicki, który po wydostaniu się z Rosji bolszewickiej, został w okresie międzywojennym kapłanem archidiecezji wileńskiej ${ }^{14}$.

Wioska Kresławka przestała istnieć pod koniec lat 30 -tych XX wieku. Mieszkańcy Aleksandrówki położonej $15 \mathrm{~km}$ od Kresławki, pamiętają jak jeszcze długo stał pośród opuszczonej wsi fundament kościoła ${ }^{15}$.

W podobnej sytuacji walki z biurokratyzmem administracji syberyjskiej okazali się mieszkańcy wsi Kanok gminy rybińskiej. Liczba osadników wynosiła 400 osób, przybyłych przeważnie z guberni grodzieńskiej ${ }^{16}$. W sprawozdaniu ze swego wiejskiego zebrania, które odbyło się 31 sierpnia 1900 r. Polacy, pisali: „...żyjemy jak zagubione owce $w$ lesie bez pasterza i potrzebnych pouczeń dla duszy. To smutne położenie pobudza nas do podjęcia jakiejś decyzji i po naradzie zadecydowaliśmy: $\mathrm{z}$ naszego środowiska wybrać na przedstawiciela chłopa Antoniego Szycko i zwrócić się do jenisejskiego gubernatora z prośbą o budowę w naszej wsi w Kanoku kościoła. Prosić o wydzielenie środków na budowę kościoła i utrzymanie parafii, bo z powodu swojej nędzy nie mając pieniędzy możemy tylko dostarczać do miejsca budowy potrzebne materiały ${ }^{17}$ ". Pełnomocnik Antoni Szycko, od 1902 r. pełnomocnik Ignacy Pawłowski, domagając się pozytywnego rozpatrzenia tego problemu wysyłali prośby do biur miejscowych i centralnych resortów i dostawali formalne odpowiedzi i odmowy. Na przykład z departamentu do spraw wyznań przyszła taka odpowiedź: ,..zalecamy zwrócić się proszącemu [Szycko] do naczelnictwa gubernialnego ${ }^{18}$ " Natomiast naczelnictwo gubernialne w Krasnojarsku i Irkucku kierowało się opinią jenisejskiej prawosławnej diecezji, która była nieprzychylna innym wyznaniom. Na zapytanie gubernatora Pleca w sprawie prośby Szycko, biskup Jefimij tak samo, jak przy rozpatrzeniu prośby przesiedleńców okręgu minusińskiego, polecił odmówić, tłumacząc to małą liczbą katolików. Oprócz tego biskup wyraził swoją pozycję oskarżając przesiedleńców katolików. W dniu 23.03.1902 r napisał: ,... w związku z małą liczbą katolików wsi Kanokskiej oraz ze względu na ich wrogie nastawienie wobec prawosławnych, które wyrażone jest chęcią katolików prześladowania prawosławnych

w Cesarstwie rosyjskim, s. 303.). Zob.: Krajowe Archiwum Państwowe w Krasnojarsku, zespół 595, inw.8, vol.5844, k. 38.

${ }^{14}$ Majdowski, Kościół katolicki w Cesarstwie rosyjskim, s. 66.

${ }^{15}$ Audio-materiały z wyprawy etnograficznej Chakaskiego muzeum krajoznawczego. Abakan, wrzesień $2003 \mathrm{r}$.

16 Rosyjskie Państwowe Archiwum Historyczne w Sankt Petersburgu, zespół 826 Kancelaria metropolity, inw. 1, vol. 1661, k. 7.

${ }^{17}$ Rosyjskie Państwowe Archiwum Historyczne w Sankt Petersburgu, zespół 826 Kancelaria metropolity, inw. 1, vol. 1661, k. 7.

${ }^{18}$ Krajowe Archiwum Państwowe w Krasnojarsku, zespół 595 Jenisejski urząd gubernialny, inw.8, vol.4765, k. 15. 
w ich życiu codziennym z powodów religijnych, jenisejska kuria biskupia nie uważa prośbę katolików wsi Kanokskiej za uzasadnioną i sądzi, że odpowiedź na ich prośbę musi być odmowna ${ }^{19}$ ". Mimo wstawiennictwa ze strony powiatowego naczelnika policji oraz wikarego kościoła w Krasnojarsku Polacy musieli budować kościół także na swój koszt. Pod koniec 1907 r. kościół pw. MB Ostrobramskiej został zbudowany. Posługa księży odbywała się dwa razy do roku przez księży z macierzystej parafii w Krasnojarsku. Na stałe przy kościele osiadł ks. Jan Jurgilanis ${ }^{20}$, nominalnie przeznaczony do obsługi uchodźców wojennych ${ }^{21}$. Kościół i plebania do roku 1922 były „w najlepszym porządku”. Po rekwizycji w 1923 roku przez państwo, drewniany kościół był wykorzystywany jako spichlerz. Wspólnota katolicka odrodziła się na początku lat 90 -tych. W 1993 r. została zarejestrowana a kościół został zwrócony wiernym ${ }^{22}$.

Niechęć władz lokalnych Syberii do wspierania budowy kościołów we wsiach polskich osadników zmniejszała proces migracji polskich chłopów. Sytuacja ta zaniepokoiła władze w Petersburgu, które zaczęły dostrzegać wyższą wartość polskiego elementu etnicznego jako bardziej upartego i przywiązanego do ziemi niż miejscowa ludność. Nie może zatem dziwić pismo Naczelnika Głównego Zarządu Przesiedleńczego, hr. G. Glinki, do Metropolity Arcybiskupa Mohylewskiego Wincentego Kluczyńskiego z 25 III 1914 r., w którym pisał, że polska ludność z guberni polskich i białoruskich przesiedlona do Azji: ,wkrótce przywyknie do miejscowych warunków, nie patrząc na trudności i ogólne warunki życia, ale to dzięki pracowitości, miłości do ziemi i bardzo szybko staje się dobrymi gospodarzami $^{23}$. Oczywiście hr. Glinka nie omieszkał zaznaczyć, że chociaż wielu z nich nie miało swojej ziemi w Ojczyźnie, to jednak na Syberii szuka polepszenia swojego bytu emigrując do Rosji. Zapewniał też Metropolitę, że jego urząd troszczy się o gospodarcze urządzenie osiedleńców i o ich religijne potrzeby, i to nie tylko prawosławnych, ale i katolików oraz że daje pieniężne zapomogi na budowę domów i katolickich kościołów ${ }^{24}$. Dla należytego zaznajomienia polskich chłopów z problemami przesiedlenia za Ural, Główny Zarząd Przesiedleńczy wydał w 1914 r., w języku polskim i rosyjskim, 47-stronicową książeczkę - broszurę pt. Przesiedlenie za Ural na rok 1914. Książeczka ukazała się w Sankt Petersburgu w nakładzie 100 tys. egz. i miała być bezpłatnie rozpowszechniona wśród ludności „Przywiślańskiego Kraju” przez urzędy gminne ${ }^{25}$.

${ }^{19}$ Krajowe Archiwum Państwowe w Krasnojarsku, zespół 595 Jenisejski urząd gubernialny, inw.8, vol.4765, k. 16-17.

${ }^{20}$ Jurgilanis Jan. Uciekinier wojenny z diec. sejneńskiej. Pracował wśród uchodźców wojennych w gub. jenisejskiej i Kanok (1915-1921). Wikariusz w Krasnojarsku (po1921-1922). Kapelan w Kanoku (po1915-1921). (Zob. Majdowski, Kościót katolicki w Cesarstwie rosyjskim, s. 301.).

${ }^{21}$ Majdowski, Kościół katolicki w Cesarstwie rosyjskim, s. 63.

${ }^{22}$ Tamże.

${ }^{23}$ W. Masiarz, Migracja chłopów polskich na Syberię w końcu XIX i na poczq̨tku XX wieku, w: Syberia w historii i kulturze narodu polskiego, red. A. Kuczyński, Wrocław 1998, s. 239.

${ }^{24}$ Tamże.

${ }^{25}$ W. Masiarz, Mała Polska Ojczyzna na Syberii Wschodniej. Polska wieś Wierszyna (19101990), „Krakowskie Studia Małopolskie”, 1-2 (1998) s. 41. 
Z lektury korespondencji Metropolity Arcybiskupa Mohylewskiego Wincentego Kluczyńskiego z parafiami syberyjskimi oraz z bogatej dokumentacji poszczególnych parafii wynika, że polska ludność przesiedleńcza borykała się $\mathrm{z}$ wielkimi problemami. $\mathrm{Z}$ trudem walczyła o każdy grosz na pokrycie kosztów pasterskich podróży księży katolickich, którzy docierali do rozproszonych i oddalonych od większych miast „,przesiedleńczych osad”. Nadto dowiadujemy się jak długa była rosyjska droga urzędowa na uzyskanie pieniężnej, najczęściej bezzwrotnej, pożyczki na budowę drewnianej kaplicy czy szkoły w nowym punkcie osiedlenia katolików, w zdecydowanej większości Polaków ${ }^{26}$. Wybuch I wojny światowej w połowie 1914 r. zakończył dobrowolną, przesiedleńczą migrację Polaków na Syberię.

\author{
DER BAU KATHOLISCHER KIRCHEN FÜR POLNISCHE ANSIEDLER IN KRESLAWKA \\ UND KANOK IM JENISSEI-GOUVERNEMENT ZU BEGINN DES 2O. JAHRHUNDERTS
}

\author{
Zusammenfassung
}

Die Emigration aus den polnischen Gebieten begann seit der zweiten Hälfte des 19. Jahrhunderts beträchtliche Ausmaße anzunehmen. Die Gesamtzahl der Emigranten aus dem Königreich Polen (Kongresspolen) ins Innere Russlands betrug ungefähr 400.000 bis 600.000 Personen (Stand um 1910).

Die römisch-katholischen Kirchen in den sibirischen Dörfern entstanden auf Initiative ihrer Bewohner, nicht selten erst nach jahrelangen Kämpfen mit der russischen Bürokratie.

Besonders benötigten die polnischen Katholiken in der Gemeinde Salbinsk im Bezirk Minussinsk eine Kirche, weil die $400 \mathrm{~km}$ betragende Entferung von Krasnojarsk nur seltene Seelsorgebesuche eines Priesters erlaubte. Da sie von den örtlichen Behörden keinerlei Unterstützung erhielten, wandten sich die Ansiedler an die römisch-katholischen Diözesen in den westlichen Verwaltungsbezirken Russlands. Im Ergebnis langwieriger Bemühungen wurde diese Kirche dann auch gebaut, aber nicht in Algasztyk, sondern in der Tjulginsk-Kolonie Kreslawka. Nach Erlangung der Baugenehmigung im Jahre 1906 besteuerte sich die Pfarrgemeinde selbst mit je 40 Kopeken pro Person, um das nötige Baumaterial einkaufen und herbeischaffen zu können, während der Arbeitslohn jeweils aus Regierungsmitteln ausgezahlt wurde. 1908 wurde die Holzkirche St. Antonius eingeweiht, und Ksawery Marcynian wurde ihr erster Pfarrer.

In einer ähnlichen Kampfsituation mit der russischen Verwaltungsbürokratie befanden sich auch die Bewohner des Dorfes Kanok in der Gemeinde Rybinsk, die aus dem Gouvernement Grodno nach Sibirien gekommen waren. Gegen Ende des Jahres 1907 wurde die der Gottesmutter vom Tor der Morgenröte (Matka Boża Ostrobramska) geweihte Kirche errichtet. Zweimal im Jahr kamen Priester aus der Heimatpfarrei hierher, um die nötige Seelsorgearbeit zu leisten.

Die Abneigung der Behörden, den Kirchenbau in den Dörfern polnischer Sibiriensiedler zu unterstützen, minderte den Migrationsprozess polnischer Bauern. Der Ausbruch des 1. Weltkrieges 1914 setzte dann der freiwilligen Ansiedlungsmigration der Polen nach Sibirien ein Ende.

Aus dem Polnischen übersetzt von Herbert Ulrich

26 Tamże. 